\title{
INTERNATIONAL ORGANIZATIONS IN THE COLD WAR: THE CIRCULATION OF EXPERTS BEYOND THE EAST-WEST DIVIDE
}

\author{
MICHEL CHRISTIAN \\ UNIVERSITY OF GENEVA \\ SANDRINE KOTT \\ UNIVERSITY OF GENEVA \\ ONDŘEJ MATĚJKA \\ CHARLES UNIVERSITY, PRAGUE, UNIVERSITY OF GENEVA
}

\begin{abstract}
This article aims to explain the existence and longevity of East-West contacts across the Iron Curtain between groups of actors in various international organizations. Three particular organizations, the International Labour Organization (ILO), the UN Conference on Trade and Development (UNCTAD), and the World Council of Churches (WCC), were chosen, all of which were involved in social, economic, and cultural issues. The official discourses of the era were clearly built in opposition to each other on each side of the Iron Curtain. This study allows us to understand the necessary conditions for the constitution of the groups of experts in the organizations who succeeded in working together, while still acknowledging their ideological differences. A focus on individual and collective actors and their career trajectories enables us to examine a hypothesis that specific "epistemic communities" gradually formed, based on convergent conceptions of modernity. In order to emphasize the global aspects of this process, our analysis pays attention to the North-South dimension as well as the East-West contacts. It examines the roles and perceptions of

We are thankful for support from the Fonds national suisse (the "Shared modernities or competing modernities? Europe between West and East, 1920s-1970s" project, based at the University of Geneva), and the PRVOUK and UNCE research funding schemes (Charles University, Prague). Michel Christian works as a research associate at the University of Geneva. Sandrine Kott is professor of contemporary European history at the University of Geneva. Ondřej Matějka teaches contemporary European history at the Charles University, Prague, and collaborates with the University of Geneva as an associate researcher. Address correspondence to Dr. Michel Christian, Département d'histoire générale, Université de Genève, 5 rue de Candolle, CH-1211 Genève 4. E-mail: michel.christian@unige.ch.
\end{abstract}


recently decolonized countries inside the chosen international organizations in order to identify another element contributing to the organizations' stability.

Keywords: transnational history; international organizations; Cold War; epistemic communities DOI: $10.14712 / 23363231.2017 .17$

\section{Introduction}

The end of the Cold War contributed to a change in the way historians regard that era of world history. Researchers are now more interested in the nature of that conflict than in the superpowers' respective responsibilities in the period. ${ }^{1}$ Taking a global approach, historians emphasize the role of decolonized spaces and analyze them as historical actors in their own right, and no longer merely as places for confrontation between the two blocs. Some historians have demonstrated the porosity of the "Iron Curtain" and the previously unremarked scale of circulation of people, ideas, and skills between Europe's East and West. These circulations have been identified and studied from multiple angles (within nations, congresses, associations, and international organizations) and in several domains (science, culture, and politics). ${ }^{2}$ This article aims to understand and explain the existence and longevity of these connections by examining certain groups of actors that established and maintained varied contacts within some international organizations.

1 Within this plethora of literature, see the remarks of Akira Iriye, "Historicizing the Cold War," in The Oxford Handbook of the Cold War, ed. Richard H. Immerman and Petra Goedde (Oxford: Oxford University Press, 2013), 15-32; and Pierre Grosser, Les temps de la guerre froide: réflexions sur l'histoire de la guerre froide et sur les causes de sa fin (Brussels: Complexe, 1995), especially 19-69. See also Odd Arne Westad, The Global Cold War: Third World Interventions and the Making of Our Times (Cambridge: Cambridge University Press, 2005), and for an intriguing neo-Marxist approach, see Richard Saull, The Cold War and After: Capitalism, Revolution and Superpower Politics (London: Pluto Press, 2007).

2 Among the rich and growing historiography in this field (labeled "new Cold War historiography") see in particular Alexander Badenoch and Andreas Fickers, Materializing Europe Transnational Infrastructures and the Project of Europe (Basingstoke: Palgrave Macmillan, 2010); Jeremi Suri, "Conflict and Co-operation in the Cold War: New Directions in Contemporary Historical Research,” Journal of Contemporary History 46, No. 1 (January 2011): 5-9, doi: 10.1177/0022009410383293; Peter Romijn, Giles Scott-Smith, and Joes Segal, eds., Divided Dreamworlds?: The Cultural Cold War in East and West (Amsterdam: Amsterdam University Press, 2012); Sari Autio-Sarasmo and Katalin Miklóssy, eds., Reassessing Cold War Europe (Abingdon: Routledge, 2013); Frederico Romero and Angela Romano, eds., European Socialist regimes facing globalisation and European co-operation: dilemmas and responses, special issue of the European Review of History 21, No. 2 (2014); Egle Rindzeviciute, The Power of Systems. How Policy Sciences Opened Up the Cold War (Ithaca, NY: Cornell University Press, 2017); Matthieu Gillabert and Tiphaine Robert, Zuflucht suchen. Phasen des Exils aus Osteuropa im Kalten Krieg / Chercher refuge. Les phases d'exil d'Europe centrale pendant la Guerre froide (Basel: Schwabe, 2017). 
We chose international organizations as our research fields because they are good observatories for identifying the nature and form of encounters and circulations. We will show that, far from being simply arenas where the states of each bloc faced off against each other, international organizations (and especially their secretariats) were sites of continuous discussion, mutual observation, exchange, and cross-acculturation. These interactions were closely connected to the very nature of these organizations, which are primarily sites for the elaboration and production of expert discourse to support the legitimacy of the organizations' recommendations and influence with states and other international organizations. ${ }^{3}$ We discuss the extent of, and the conditions underlying, the ability of the international organizations to arbitrate, maintain, and produce communities of experts that possessed a common group culture (i.e. a set of persuasions, opinions, argumentative patterns, and institutional strategies linked to their professional socialization inside their organization and/or their area of expertise). We call these groups “epistemic communities." In this sense, we base our analysis on the well-known definition of epistemic community introduced by Peter Hass in the 1992 special issue of International Organization, which he meant to capture the reality of a "network of professionals with recognized expertise and competence in a particular domain and an authoritative claim to policy-relevant knowledge within that domain or issue area." ${ }^{4}$ We also take into account recent debates on epistemic communities, emphasizing the necessity of carefully examining their internal coherence and the specific internal group dynamics that to a varying degree limited or enhanced their influence in a transnational world. ${ }^{5}$

Our work is primarily based on the activities of three organizations: the International Labour Organization (ILO), the United Nations Conference on

3 Madeleine Herren, Geschichte der internationalen Organisation (Darmstadt: WBG, 2009), 1532; Bob Reinalda, Routledge History of International Organizations: From 1815 to the Present Day (London: Routledge, 2009), 347-583. See also Akira Iriye, Global Community: The Role of International Organizations in the Making of the Contemporary World (Berkeley, CA: University of California Press, 2002), especially 37-74; Sandrine Kott, "Par-delà la guerre froide: Les Organisations Internationales et les circulations Est-Ouest (1947-1973)," Vingtième Siècle. Revue d'histoire 109 (January-March 2011): 143-55, doi: 10.3917/vin.109.0142; Sandrine Kott, "Cold War internationalism," in Internationalisms. A Twentieth-Century History, ed. Glenda Sluga and Patricia Clavin (Cambridge: Cambridge University Press, 2016), 340-63.

4 Peter Haas, "Introduction: Epistemic Communities and International Policy Coordination," International Organization 46, No. 1 (Winter 1992): 1-35, here page 3.

5 Mai'a K. Davis Cross, "Rethinking epistemic communities twenty years later," Review of International Studies 39, No. 1 (January, 2013): 137-60, doi: 10.1017/S0260210512000034; Yves Viltard, "L'étrange carrière du concept foucaldien d'épistémè en science politique," Raisons politiques 23 (2006): 193-202, doi: 10.3917/rai.023.0193. 
Trade and Development (UNCTAD), and the World Council of Churches (WCC). The choice of these three research sites was determined mainly by the quality and accessibility of sources ${ }^{6}$ but they also proved to be especially heuristic for two reasons. Firstly, the organizations are concerned with social, economic, and cultural themes about which the official discourses of the Cold War era held opposing views. This opposition of viewpoints did not, however, prevent observable convergence in how economic and social policies were formulated and implemented by each side. The convergence was the result of joint analysis of the issues of training, development, and secularization, whose rationales and genealogies we will try to reconstruct. Secondly, these organizations are diverse in their chronologies, domains of intervention, and modes of operation, allowing exploration of a great variety of actors representing diverse cultures, who nonetheless converged around a common episteme.

The ILO is the oldest of the three organizations. It was founded in 1919 to meet demands for reform formulated by socialist union organizations during World War I. It is comprised of representatives from states, employers, and labor. It promoted the internationalization of social reforms, clearly in response to the Bolshevik revolution. Initially focused on developing conventions promoting international social policy in response to unions' demands dating back to the nineteenth century, the ILO began offering technical and development assistance to less-developed economies during the economic crisis of the 1930s. This assistance was scaled up after $1945 .{ }^{7}$ We will focus on this development program because it puts the circulation of experts and the convergences of policy-making into the sharpest relief.

UNCTAD is another example of international organization that promoted or created cross-cultural rapprochement in the economic domain. It was the

6 In order to complete the one-sided and one-dimensional perspective of their own action that international organizations present in their official documents, we made a systematic effort to get access to correspondences of the main actors (which we found in the ILO and WCC archives). We also consulted several national-level institutional funds and conducted interviews with accessible living witnesses (for the WCC and UNCTAD case studies).

7 The number of publications on the ILO has proliferated in recent years, adding to classics such as Antony Alcock, History of the International Labour Organisation (New York: Octagon Books, 1971) and Victor-Yves Ghebali, The International Labour Organization: A Case Study on the Evolution of U.N. Specialised Agencies (Dordrecht: Martinus Nijhoff, 1989). See also recent edited volumes by Jasmien van Daele et al., eds., ILO Histories: Essays on the International Labor Organization and its Impact on the World during the Twentieth Century (Bern: Lang, 2010); Isabelle Lespinet-Moret and Vincent Viet, eds., L'organisation internationale du travail: origine, développement, avenir (Rennes: Presses universitaires de Rennes, 2011); Sandrine Kott and Joëlle Droux, eds., Globalizing Social Rights: The ILO and Beyond (Basingstoke: Palgrave Macmillan, 2013). 
fruit of an inaugural conference in 1964, and was then institutionalized in the form of an international organization with a General Secretariat initially headed by Raul Prebisch. UNCTAD's mission is promoting development through trade. Its activities are not limited to studying and reducing tariff barriers (like the institutions responsible for the GATT, for instance), but instead also address the conditions that make free trade possible, be they material (transportation fleets, communications networks) or institutional (banking institutions, removal of economic barriers, and inter-state agreements) ${ }^{8}$ Economic development was the central concern at UNCTAD. It relegated Cold-War antagonisms to the background while acknowledging the differences between systems, as shown by the existence of a Division for Trade with Socialist Countries, which we will study in particular detail.

In the seemingly quite unrelated domain of religion, the ecumenicalism preached by the WCC allowed it to function as another site for overcoming Cold War hostility. The WCC was founded in Amsterdam in August 1948, but the idea for such an organization had been under discussion since the 1930s. In the decades after its founding, the Geneva-based WCC managed to bring together most of the non-Roman Catholic churches in the world (147 in 1948, 348 in 2017)..$^{9}$ Its membership was predominantly Protestant and Euro-American in the 1950s, but the WCC's profile and identity changed in the 1960s with the entry of several Eastern Orthodox churches and new independent churches from decolonized countries of the world's South. ${ }^{10}$ The global spread of the WCC crowned

${ }^{8}$ Most of the literature on UNCTAD dates back to the 1970s, when the organization was viewed as a central actor in redefining the "New International Economic Order," see Georges Merloz, La CNUCED. Droit International et Développement (Bruxelles: Bruylant, 1980); Boualia Benamar, La CNUCED et le nouvel ordre économique international (Paris: Université de droit, d'économie et de sciences sociales, 1984); Robert L. Rothstein, Global Bargaining: UNCTAD and the Quest for a New International Economic Order (Princeton, NJ: Princeton University Press, 1979). UNCTAD has just recently attracted a new wave of interest from historians, especially since the 2008 financial crisis: see Johanna Bockman, "Socialist Globalization against Capitalist Neocolonialism: The Economic Ideas behind the New International Economic Order," Humanity: An International Journal of Human Rights, Humanitarianism, and Development 6, No. 1 (2015): 109-28, doi: 10.1353/hum.2015.0010; Sönke Kunkel, "Contesting Globalization: The United Nations Conference on Trade and Development and the Transnationalization of Sovereignty," in International Organizations and Development, 1945-1990, ed. Sönke Kunkel, Corinna Unger, and Mark Frey (Basingstoke: Palgrave Macmillan, 2014), 240-59.

9 See "What is the World Council of Churches?," official website of the WCC, http://www .oikoumene.org/en/about-us.

${ }^{10}$ Besides classical, certainly well-informed, WCC-sponsored accounts of the organization's history, including Ruth Rouse and Stephen Neill, A History of the Ecumenical Movement 1517-1948 (Geneva: World Council of Churches, 1986) and Harold E. Fey, The Ecumenical Advance: A History of the Ecumenical Movement (Geneva: World Council of Churches, 1986), the WCC 
the efforts of the group of theologians that headed the WCC until the late 1960s. They were distinguished by a particular conception of ecumenicalism that was closely tied to the dialectic theology of Karl Barth, which decried any attempt to identify a religion with a political system.

We will use these three research sites to demonstrate the conditions precedent for the constitution of groups of "pan-European" experts who succeeded in working together while acknowledging or even asserting their ideological differences. We will then explore whether their collaboration is evidence of the existence and gradual evolution of a specific language among them, or even a common epistemic foundation based on convergent representations of modernity. In that way, we can address the question of whether those groups may be considered as epistemic communities. To study the construction of this common culture we will start by identifying the individual and collective actors who supported it. We will first describe the profiles of these groups or communities, and then try to understand the reasons for their cohesiveness by tracing back their long genealogies. Lastly, in order to identify an element contributing to the stability of the expert groups, we will examine how they perceived recently decolonized countries and how they related with that part of the world.

\section{The Creation of an Episteme}

All officials and experts participating in the activities of international organizations during the Cold War were faced with the split between "East" and "West," which played out in large international conferences and in the United Nations Security Council. Representatives of international organizations chose different strategies for navigating this conflict. They differed in their terminological choices for designating Eastern, Western, and non-aligned countries. They also differed in the approaches they took to the Cold War divide, which they could ignore (the ILO), surpass (UNCTAD), or integrate into their own initiatives (the WCC). In each case, these strategies spoke to the existence or constitution of a specific group culture based on the exchange of information and cross-acculturation.

\footnotetext{
has attracted the attention of a younger generation of researchers, among them Matti Peiponen, Ecumenical Action in World Politics: The Creation of the Commission of the Churches on International Affairs (CCIA), 1945-1949 (Helsinki: Luther-Agricola-Society, 2012) and mainly Katharina Kunter and Annegreth Schilling, Globalisierung der Kirchen: der Ökumenische Rat der Kirchen und die Entdeckung der Dritten Welt in den 1960er und 1970er Jahren (Göttingen: Vandenhoeck \& Ruprecht, 2014).
} 


\subsection{Sites and Institutions Where Groups Were Created}

International organizations were founded to favor the exchange of information and to encourage peace and harmony between nations. They are dedicated to being spaces for discussion and reconciliation, including (or even especially) during tense periods of political conflict. In this respect, all three of our research sites demonstrate that the Cold War was an especially fertile time for international organizations that could serve as meeting places, especially for a Europe that was cut in two.

This bridging role could even be the reason for an organization's very existence and an important element in its legitimacy, as was the case for the WCC. Indeed, the WCC positioned itself early on to overcome the division of Europe arising from the Cold War. Ecumenicists from the East and West accepted the new geopolitical division and turned it into an opportunity to demonstrate the value of building ecumenical unity. Because of its rarity in the bipolar world, "political ecumenicalism" contributed to the WCC's prestige. The WCC secretariat's strategic gamble was to display opposition to the Cold War in an especially striking way and assert the WCC's unique ability to overcome it. Arbitrating between the extreme positions represented by John Foster Dulles, a staunchly anti-communist Presbyterian and future U.S. Secretary of State, and the Czech theologian and communist sympathizer Josef L. Hromádka, ${ }^{11}$ the WCC's founding assembly of 1948 ended up under the influence of the Swiss theologian Karl Barth. It adopted a motion expressing an ecumenical position with respect to East-West antagonism: "the Christian churches should reject the ideologies of communism and laissez-faire capitalism and should seek to draw men away from the false assumptions that these extremes are the only alternatives." 12 This position was rare in the frozen context of the early Cold War period. It guided the efforts of the WCC's secretariat, headed by Willem Visser 't Hooft of the Netherlands, who managed to maintain the participation of representatives of the East in the WCC throughout the 1950s. ${ }^{13}$ The secretariat's strategy, supported

11 File 31.004/01, 02, 03, World Council of Churches Archives (WCCA), Geneva. On Hromádka, see a recent biography by Peter C.A. Morée and Jiří Piškula, Nejpokrokovější církevní pracovník: protestantské církve a Josef Lukl Hromádka v letech 1945-1969 (Benešov: EMAN, 2015).

12 File 31.003/15, WCCA, Geneva. See also the testimonial by Lukas Vischer, "The World Council of Churches and the Churches in Eastern Europe during the Time of the Communist Regimes: A First Attempt at an Assessment," Religion, State and Society 25, No. 1 (1997): 62.

${ }^{13}$ For example, file 42.3.035/4, WCCA, Geneva. The continuing presence of representatives of the East would, of course, have been impossible without a sometimes more or less tolerant attitude on the part of the Communist regimes. In the Czechoslovak case, it is possible to observe different 
by the WCC ecumenicists' worldwide ambitions, was crowned with success in 1961, when the Soviets decided to authorize the Russian Orthodox Church to join the organization. For the WCC leadership, this expansion to the East symbolized the organization's having overcome the double limitation of being Euro-American and Protestant, a perception that had typified the ecumenical movement since the late nineteenth century. ${ }^{14}$ From their perspective, the Cold War allowed them to deepen an integrative ecumenical process which certain observers termed a "second Reformation."15

A different process was underway at the ILO, where moving beyond ideological oppositions resulted less from an initial ecumenical will than from a rapprochement based on convergences that had appeared in ILO practice without necessarily being explicitly formulated. Training programs for labor and management, one of the ILO's specialties under the UN development program, were places where encounters could take place and convergences between Eastern and Western Europe could emerge. These training programs were supported by a common productivist objective that led to the export of skills from the West to the East in the 1950s, by means of development programs implemented by the ILO's secretariat under the auspices of the UN Development Programme (UNDP). There were three discernible contexts for these encounters, the first being study trips. Between 1957 and 1960 several Polish fellowship recipients studied in professional reconversion programs in West Germany, France, and Great Britain. ${ }^{16}$ The Romanian Minister of Foreign Affairs received ILO grants for industrial managers to pursue studies relevant to Romania's strongest industries (petroleum, textiles, and agro-food) in Western countries ${ }^{17}$; the Bulgarians

ways in which East-West contacts were instrumentalized inside the WCC by Communist leaders on both the national and international level. On this point and on the use of Josef Lukl Hromádka as an "export good," see Ondřej Matějka, "Jsou to berani, ale můžeme je využít. Čeští evangelíci a komunistický režim 1948-1956," Soudobé dějiny 14, No. 2-3 (2007): 305-40 and Ondřej Matějka, "Apprendre à vivre dans une dictature. Le milieu protestant tchèque 1948-1956," Transitions 47, No. 12 (2007): 13-31. The Czechoslovak secret police (Státní bezpečnost) was understandably very intensely interested in the activities of all Czechoslovak citizens involved in international organizations. Most of the key domestic files on them were destroyed shortly after 1989, however. We can thus work with only fragmentary sources - for example files 10336 and 10453 in the archival holdings of the Hlavní správa rozvédky, Archiv bezpečnostních složek (Security Services Archives, Prague).

14 Willem Adolph Visser 't Hooft, Memoirs (Geneva: WCC Publications, 1987), 254-76.

15 “The Russians Join the World Council," Time, December 1, 1961.

${ }^{16}$ See request addressed to Director General David Morse, files Z 3/64/2 and OTA 50-1 (A), International Labour Organization Archives (ILOA), Geneva.

17 File Jenks Papers 1968, ILOA, Geneva. 
followed suit. ${ }^{18}$ During the period of economic reform in the 1960s, when Eastern bloc businesses were granted greater independence, management training became essential. Upon the request of the political leaders of several socialist countries, the ILO Office established management training centers, which were the second context for East-West encounters. The first such center was established in Warsaw in 1965, and all Eastern Bloc countries (with the exception of the German Democratic Republic [GDR] and the USSR) would eventually get their own centers. ${ }^{19}$ In Romania the CEPECA (Centrul de Perfectionare a Cadrelor de Conducere din Întreprinderi), founded in 1967, has remained a model to this day. Bulgaria got a management training center for engineers, scientists, and government bureaucrats in $1969 .{ }^{20}$ The Turin training center for management in developing countries represents the third setting for encounters. The Czechoslovak government sent its first group of managers there in 1969.21 It was during these trips and at these centers that leadership from the East met its peers of the West, and this is where a common language and episteme gradually developed between them.

UNCTAD's vocation for development was initially backed by the "Group of 77." UNCTAD successfully imposed a way of working and forms of discourse on its members, which reduced the divisions of the Cold War without erasing them. Its approach was characterized by numerical and political domination by "developing countries" (group A) and Latin American countries (group C) over "developed market-economy countries" (group B) and "socialist countries" (group D), both in the UNCTAD General Assembly and in its executive body, the Trade and Development Board. Cross-cutting alliances were impossible because each of these groups had its own deliberative process for arriving at a common position. This situation favored the independence of the "developing countries" group, despite its heterogeneity. Legitimized discursive forms, starting with the nomenclature used to designate the country groups, were also significant factors in neutralizing antagonism. To be acceptable, they had to be formulated in terms of increasing opportunities for trade benefiting the development of countries in groups A and C. The perspective shifted from competition between two opposing political models to one based on a single value scale: development.

\footnotetext{
18 File UNDP 10-2-C-2-2 (1), ILOA, Geneva.

${ }^{19}$ Correspondence 1966-1969, file Z/1/10/1/1, ILOA, Geneva.

${ }^{20}$ Wynne Roberts report on mission to Bulgaria, October 10-17, 1970, file MI 221, ILOA, Geneva.

${ }^{21}$ File TAP 0-17, ILOA, Geneva.
} 
This discursive and practical adjustment proved to be particularly good for Eastern Bloc countries. There was even an office in the UNCTAD General Secretariat called the Division for Trade between Countries with Different Economic Systems, which was specifically charged with promoting trade between developing and socialist countries (as revealed by its shortened name, the "TRADSOC division"). This division's very existence, with no equivalent on the side of developed market-economy countries, ${ }^{22}$ was an implicit privilege granted to socialist countries. Likewise, its composition seems to be the result of a compromise with the Eastern Bloc countries, the USSR chief among them: the division directors were invariably from the Soviet Union and division members were predominantly from Eastern Bloc countries (Bulgaria, Czechoslovakia, and including Yugoslavia). Some members were civil servants from developing countries (Algeria, India, Pakistan) and neutral European countries (Switzerland, Austria, Finland, Sweden).

\subsection{The Gradual Constitution of a Common Culture of Modernity}

These development programs were able to function properly thanks to an enculturation process and the elaboration of a common language whose grammar was supplied by international-level officials and experts. This process assumed different forms and degrees of importance depending on the organization.

In the ILO's Office, the language used to discuss economic and social issues became increasingly technical and was marked in particular by the disappearance of certain words such as "capitalism" and "socialism." This is what made it possible for officials from the ILO Office and the United Nations Economic Commission for Europe (UNECE) to establish a Regional Training Institute in the Balkans (Bulgaria, Yugoslavia, Greece, Turkey) without giving a second thought to its compatibility with the economic and social systems in the countries it served. ${ }^{23}$ This project was developed by a specific group in the Office in charge of such programs that was composed of professional and management training experts schooled in the business culture of English-speaking and Nordic coun-

22 There were other sites of East-West encounters in the area of trade relations such as the UN Economic Commission for Europe (UNECE), but they had a rather limited impact. For more details on UNECE see Daniel Stinsky, "A Bridge between East and West? Gunnar Myrdal and the UN Economic Commission for Europe, 1947-1957," in Planning in Cold War Europe: Competition, Cooperation, Circulations (1950s-1970s), ed. Sandrine Kott, Michel Christian, Ondřej Matějka, forthcoming in De Gruyter.

23 File UNDP 10-2-C-2-2(2), ILOA, Geneva. 
tries. Rhys Wynne-Roberts, who was responsible for the Office's management division from 1954, came from the British Institute of Management after an earlier career in the aeronautic industry.

In practice, ILO culture was disseminated by sending out experts who shared the same background. This is how W. Carver, of the renowned Cranfield School of Management in Bedford (England), came to establish and coordinate three seminars between 1973 and 1975 in Czechoslovakia on scientific management and rationalization in industrial companies. Carver hired only British experts to run these seminars. ${ }^{24}$ John McDonald, who took charge of the labor training program in Bulgaria, was a civil servant in the American State Department, but he surrounded himself with British experts from the same managerial culture. ${ }^{25}$ These Western experts' encounter with the "natives" entailed a phase of cross-acculturation. At the beginning, both sides contributed to discord. Eastern authorities found the perspective adopted by the trainers to be too blatantly Western. On the other hand, in Bulgaria for example, ILO Office employees and experts complained that some of the courses on the "new economic order" were couched in overtly propagandistic language. ${ }^{26}$ By the 1970 s, however, language and references were clearly converging. Furthermore, circulation was in two directions. The system of training by modules ("modular employable skills") instituted by the ILO Office in the late 1970s by two British-trained professional training experts, John. D. Gilmore and William Plumbridge, actually seems to have been particularly well-suited to socialist economies, where every task in the economy was enumerated under a planning framework. ${ }^{27}$ The Soviet system of planning in turn inspired some British experts.

The shared objective of development and modernization, paired with the concept of economic and social engineering, opened possibilities for dialogue. At UNCTAD, whose purpose was to promote trade in the service of development, the difference between socialist and developed market-economy countries was clearly secondary to that between "developing countries" and "developed countries." Among the latter, however, UNCTAD did further distinguish between "developed market-economy countries" and "socialist countries." This way, Eastern Bloc countries preserved their ideological distinctiveness while avoiding language that implied that they were "developed," which would place them vexingly close to Western Bloc countries. The linguistic categories

\footnotetext{
${ }^{24}$ File UNDP 17-2-b-1-1, ILOA, Geneva.

25 File MI 221, ILOA, Geneva.

26 Wynne Roberts' report on mission to Bulgaria, October 10-17, 1970, MI 221, ILOA, Geneva.

27 Plumbridge's report on mission to Bulgaria, July 1980, UNDP 10-2-C-2-2 (2), ILOA, Geneva.
} 
developed at UNCTAD attest to a compromise with the schism of the Cold War that favored the Eastern Bloc countries. The organization had to make a constant effort to impose these categories on all collaborating actors, who in many cases were required to revise their own statistical data to respect UNCTAD nomenclature. Countries such as Turkey (a member of NATO) were counted among developed market-economy countries, while Yugoslavia, Cuba, China, and Vietnam were considered to be developing, not socialist, countries.

In the case of the WCC, Eastern and Western actors' ability to place themselves between or above the two blocs depended on a theological identity that predated the Cold War and the WCC's founding, but which took on a new meaning during the post-1945 period. The vocabulary and grammar of the WCC's language were based on Karl Barth's dialectic theology, which dominated the protestant theological landscape from the 1930s through the 1960s. ${ }^{28}$ Among its most fervent followers were Willem Visser 't Hooft (Dutch), Pierre Maury (French), and Josef L. Hromádka (Czech). Barthian theology rejected the anthropocentrism of pre-1914 liberal theology and relied on a resolute affirmation of the transcendence of God. These theologians made a radical distinction between the human and the divine and rejected any confusion of the theological and the political. ${ }^{29}$ Their theology (and its Eastern European variant in particular) hailed the end of the "Constantinian era," or in other words, the end of privileged relations between church and state. ${ }^{30}$ This laid the groundwork for the WCC to become a site for inter-bloc dialogue in the late 1950s, and even made the (more rapidly) secularizing East seem like a source of inspiration for the West. Indeed, the theologians dominating the WCC favorably assessed the "unique contribution" of Eastern European Christians living in atheistic (even actively anti-religious) states. Those states had already passed into the "post-Constantinian era" and thus possessed an experience that could be particularly enriching for the West. ${ }^{31}$

${ }^{28}$ Conrad Simonson, The Christology of the Faith and Order Movement (Leiden: Brill, 1972), 100-105.

29 Daniel Cornu, Karl Barth et la politique (Geneva: Labor et Fides, 1968). On Barth's contacts with Czech Protestants see Jan Štefan, Karl Barth a ti druzí: pět evangelických theologů 20. století: Barth, Brunner, Tillich, Althaus, Iwand (Brno: CDK, 2005).

30 Jan Milíč Lochman, “Eine Konstantinische Kirche," Communio viatorum 1 (1958): 40-44; see also his contributions to preparatory volumes for "Church and Society" conference in 1966: John C. Bennett, ed., Christian social ethics in a changing world: an ecumenical theological inquiry (London: SCM Press, 1966), 231-52.

31 Jan Milíč Lochman, Church in a Marxist society: A Czechoslovak view (Evanston IL: Harper \& Row, 1970); Cornu, Karl Barth, 184. 
Curiosity about the communist experience was compounded among Western experts by social radicalism, a self-critical attitude toward Western civilization and a high regard for intellectual non-conformity (manifested in rejection of anti-communist discourse). These views typified the culture specific to Western actors inside the WCC. The German historian Hedwig Richter, who is quite critical of the WCC, qualified it as a linksrevolutionäres Pathos (leftist revolutionary pathos). She claimed that it would pave the way for the WCC to engage in world politics alongside the radical elements in the Third World in the 1970s and 1980s. ${ }^{32}$

\section{Experts for the Duration of the Cold War}

The stability, efficacy, and ultimate social impact of the groups that formed or appeared within the three organizations studied here also depended on those groups' ability to impose their views at a given time and place. In each of those international organizations, the experts managed to unite into a larger group that related to a longer history and that surpassed the original organization.

\subsection{The Constitution of a Broader Group of Experts}

In the organizations we studied, the core epistemic communities were composed of managers, permanent staff, and international officials. Their level of engagement was based on their rank in the bureaucratic organization, but also on their vocation and their recognized expertise in their field. For example, the Secretary General of the WCC between 1948 and 1966, Visser 't Hooft, was both a highly experienced international official (thanks to his career in the Young Men's Christian Association [YMCA] and the World Student Christian Federation [WSCF] in the 1920s and 1930s) and a respected theologian, possessing a doctorate that lent legitimacy to his active participation in all the WCC's doctrinal debates.

Outside experts gravitated to these core officials. International organizations called on the outsiders in part because their financial means were limited and in part because their political strategy called for the gradual construction of internationally recognized expertise. ${ }^{33}$ Some of these outside experts were

32 Hedwig Richter, "Der Protestantismus und das linksrevolutionäre Pathos. Der Ökumenische Rat der Kirchen in Genf im Ost-West-Konflikt in den 1960er und 1970er Jahren," Geschichte und Gesellschaft 36, No. 3 (2010): 408-36, doi: 10.13109/gege.2010.36.3.408.

33 On the importance attributed to this expertise, see critical analyses in Yves Dezalay and Bryant G. Garth, eds., Lawyers and the Construction of Transnational Justice (New York: Routledge, 2012). 
engaged as occasional consultants, and indeed such consultants produced most of the reports of the Division for Trade with Socialist Countries under UNCTAD's supervision. In other instances, they were members of international expert commissions. At the WCC, the work performed in such specialized commissions, which were painstakingly staffed according to geographical and confessional divisions, was the heart of its programmatic activities. They were numerous (19 in the 1960s) and the nomination procedure for participation on them was the result of complex negotiations. ${ }^{34}$ A similar reliance on commissions was seen in the ILO's Office as well. ${ }^{35}$ On the other hand, UNCTAD's Division for Trade with Socialist Countries only rarely relied on this type of commission. ${ }^{36}$

Around the edges of each group within the organization was an assortment of actors who participated indirectly in the epistemic community's activities. They were mainly students on fellowship in the international organization and academics seeking data and information about a particular domain of interest. In the ILO-UNDP program, they were either people trained by experts to be sent out into the field or the recipients of fellowships (the latter were usually "cadres" from socialist regimes). ${ }^{37}$ There were directors of state enterprises (as was the case for the Czechoslovaks sent to Turin in 196938) and people working as technical managers in governmental ministries. One of them was Helena Maria Larek, who was sent from Poland to France in 1958 and later became a psychological advisor in the professional expertise division of the department for vocational rehabilitation of the disabled of the Polish Ministry of Labor and Welfare. ${ }^{39}$ Lastly, there were researchers who worked in institutes with ties to power, such as the Czechoslovak experts sent to Western Europe between 1975 and 1978 for training in methods for rationalizing workflow and managing by objectives. ${ }^{40}$ These grantees' files reveal that most had previously received funding from international programs, which indicates that such academics were

34 Visser 't Hooft, Memoirs, 315.

35 For more details, see Sandrine Kott, “Une 'communauté épistémique' du social? Experts de l’OIT et internationalisation des politiques sociales dans l'entre-deux-guerres,” Genèses 71, No. 2 (2008): 26-46, doi: 10.3917/gen.071.0026.

36 It did so in 1977 (on multilateral payments) and in 1984 (on the methods and means for promoting trade between countries with different economic and social systems).

37 Sandrine Kott, "Les elites socialistes et le pouvoir. Le cas de la RDA," in Le communisme et les élites en Europe centrale. Destructions, mutations, conversions, ed. François Bocholier and Nicolas Bocquet (Paris, PUF, 2006), 169-86.

38 File TAP 0-17, ILOA, Geneva.

39 File OTA 50-1 (A) Fs-3, ILOA, Geneva.

40 File UNDP 17-2-A-1-1-FS (1), ILOA, Geneva. 
already internationalized and serving as interfaces between the socialist and capitalist worlds. While they were not necessarily an epistemic community, it is conceivable that they were a pool of recruitment for the expertise needed in the transition to capitalism after $1990 .{ }^{41}$

The impact of these communities depended on the diversity of the publics with which they interacted. Thus, in the late 1960s, upon the initiative of representatives from Eastern Europe, the WCC jointly organized and funded several meetings between (primarily European) Marxists and Christians to discuss their ideological differences and commonalities. ${ }^{42}$ Following this initiative, Ladislav Prokůpek, a Czechoslovak Marxist (and a former member of the ecclesiastical department of the Czechoslovak Ministry of Culture charged with controlling religious activities) spent several months on a WCC grant researching protestant theology at the Bossey Ecumenical Institute in Switzerland. ${ }^{43}$

Among all these circles there were natural career pathways that contributed to the construction of a common episteme. For instance, some of Hromádka's former students and theology advisees were progressively included in WCC working commissions. ${ }^{44}$ Some academics who consulted for UNCTAD were called back to participate in expert commissions, as was the case for Sumitra Chishti of the Indian Institute of Foreign Trade. Having worked upon several occasions as a consultant for the Division for Trade with Socialist Countries, Chishti was asked to participate in an international commission "on the methods and means of promoting trade between countries with different economic and social welfare systems." 45

\subsection{Pre-existing Networks}

A biographical approach makes it possible to map these career transitions and show that certain "epistemic communities" were actually rooted in an older shared framework. Links that were forged in the period between the world

${ }^{41}$ See the analysis of Johanna Bockman, Markets in the Name of Socialism: The Left-Wing Origins of Neoliberalism (Redwood City, CA: Stanford University Press, 2011).

42 Central Committee Report Heraklion (1967), file 37.0045, WCCA, Geneva.

43 File 42.03.36, WCCA Geneva; authors' interview with Ladislav Prokůpek, August 28, 2006.

${ }_{44}$ Namely Jan M. Lochman, Josef Smolík, and Milan Opočenský; see Minutes from Central Committee Meetings 1961-1968, WCCA, Geneva.

45 File ARR 40/1830, 67, TDO 287/6, UNCTAD, United Nations Archives (UNA), Geneva. Reports of the ad hoc group of experts to consider ways and means of expanding trade and economic relations between countries having different economic and social systems, March 1984-July 1984. 
wars lasted throughout the Cold War. ${ }^{46}$ In this respect, certain countries like Czechoslovakia and Poland had privileged positions as go-betweens, aided by their strong presence in international organizations before World War II. Actors who had played a part in pre-war internationalization again played a crucial role in the circulation of people and ideas during the Cold War.

The "ecumenical Barthians" who dominated the WCC's first twenty years were a case in point. ${ }^{47}$ This community began to take shape in the mid-1920s, when future members of WCC governing bodies and staff such as Visser 't Hooft, Maury, Hromádka, and von Thadden (who was German) met through the YMCA and the WSCF. Those international Christian organizations were growing rapidly at the time and were actively involved (using North American funding) in the (re)construction of the educational infrastructure for Eastern European youth. YMCA and WSCF leaders such as John R. Mott devoted particular attention to Czechoslovakia because they could rely on a national-level political elite that was very open to the West (particularly those officials who were close to President Masaryk). ${ }^{48}$ Local supporters were ready to use the state budget to help fund their initiatives. Protestant elites at the local level had already been internationalized for historical reasons. ${ }^{49}$

The Czechoslovak success story (exemplified by the YMCA) was extensively instrumentalized for publicity in the West. Contacts in Czechoslovakia were soon sought out as favored partners by their Western peers in international organizations. As secretary general of the WSCF in 1928, Visser't Hooft engaged his friend Hromádka (a professor of Protestant theology in Prague and a member of the Czechoslovak YMCA's national board) in his international endeavor to

46 Among the growing literature on that topic see Martin Kohlrausch, Kathrin Steffen, and Susan Wiederkehr, eds., Expert Cultures in Central Eastern Europe: The Internationalization of Knowledge and the Transformation of Nation States since World War I (Osnabrück: Fibre, 2010); Frank Hadler and Matthias Midell, eds., Verflochtene Geschichten: Ostmitteleuropa, special issue of Comparativ: Zeitschrift für Globalgeschichte und vergleichende Gesellschaftsforschung 20, No. 1-2 (2010); Johan Schot and Vincent Lagendijk, "Technocratic Internationalism in the Interwar Years: Building Europe on Motorways and Electricity Networks," Journal of Modern European History 6, No. 2 (2008): 196-217, doi: 10.17104/1611-8944_2008_2_196.

47 Conservative American Protestants had already started denouncing this Barthian domination by 1948; see The Christian Century 65, No. 40 (October 1948): 1033.

${ }^{48}$ For more on this aspect, see Ondřej Matějka, "Erziehung zur 'Weltbürgerlichkeit:' Der Einfluss des YMCA auf die tschechoslowakische Jugend der Zwischenkriegszeit," in Jugend in der Tschechoslowakei. Konzepte und Lebenswelten (1918-1989), ed. Christiane Brenner et al. (Göttingen: Vandenhoeck \& Ruprecht, 2016), 153-79.

49 Until 1918, there were no university institutions for training Czech Protestant ministers, so they studied in Western Europe and as a result created a rather rich network of contacts in English- and German-speaking countries. 
create a Barthian network, notably through Student World magazine. Visser 't Hooft's choice of Hromádka, as a Central European, was meant to manifest the global impact of dialectic theology. ${ }^{50}$

Hromádka escaped the Protectorate of Bohemia and Moravia in April 1939, just before the outbreak of World War II, thanks to his friends in the WSCF, who "exported" him to the United States to win over followers for the "new European [Barthian] theology." 51 He was made a professor at the Princeton Theological Seminary in 1940 and gradually became the most respected Central European theologian in North America. After 1945, he leveraged his position to bring some twenty young Czechoslovak theologians to the West. Funded by the nascent WCC, the young theologians benefited from the hospitality of seminaries in North America, Great Britain, and Switzerland. ${ }^{52}$ Some of them (such as Josef Smolík and Jan M. Lochman) in turn joined WCC working commissions in the early 1960s and contributed to the influence of the community of ecumenical Barthians in the organization.

Likewise, the managerial tradition had spread throughout Eastern Europe in the inter-war period, in the wake of the penetration of the region by capitalist interests. British (including the Bedaux Britain consultancy), German, and Dutch companies established offices in most Central European countries. ${ }^{53}$ The ILO staff had possessed significant relevant skills since the inter-war period, ${ }^{54}$ but it had not participated in exporting management techniques to the East. The ILO did, however, hire experts at the time who would later bridge East and West in the field of training. In that regard, the Polish ergonomist Jan Rosner, hired by the ILO in 1933, played an important role. In the 1950s he would negotiate the first-ever fellowship program allowing Polish students to get training in Western Europe. 55

Czechoslovakia is another country that illustrates biographical continuities across time that are vital to explaining the constitution of a community of social

${ }^{50}$ Correspondence file, Josef Lukl Hromádka (1928), Archives of the World Alliance of the YMCAs, Geneva.

51 Files 213.11.7.16 and 42.0039/2, WCCA, Geneva.

52 File 425.06.001, WCCA, Geneva.

53 J. Poor and A. Milovecz, "Management Consulting in Human Resource Management: Central and Eastern European Perspectives in Light of Empirical Experiences," Journal of Service Science and Management, 4, No. 3 (2011): 300-14, doi: 10.4236/jssm.2011.43036.

54 Thomas Cayet, Rationaliser le travail, organiser la production: Le bureau international du travail et la modernisation économique durant l'entre-deux-guerres (Rennes: Presses universitaires de Rennes, 2010).

55 Files P 2765, P 14/11/41 and Z 3/64/2, ILOA, Geneva. 
welfare experts in both Eastern and Western Europe. Anton Zelenka, head of the social insurance department in the ILO Office, encapsulates these continuities well. Born in Prague in 1903, after completing his studies he held leadership positions in the 1920s and 1930s in the Czechoslovak First Republic's central administration for social insurance. He then moved to the ILO, where he worked closely with two other Czechs who were key actors in the field of social insurance in the inter-war period ${ }^{56}$ : Oswald Stein, director of the ILO's social insurance department from 1937 to 1943, ${ }^{57}$ and Emil Schönbaum, who began developing insurance systems in the Balkans before being sent to Latin America during the war. ${ }^{58}$ In 1957, it was Zelenka who negotiated with the Czechoslovak minister Evžen Erban to hold a seminar on social insurance in Prague, with the ILO's backing, that was open to third-world countries. ${ }^{59}$ As we shall see, the exportation of expertise to the global South was a powerful tool used by this group of "social engineers" to realize their common objectives.

\subsection{The Renewal of Actors Starting in the Late 1960s}

Although some of the observed circulation of people and ideas between the two blocs can be explained by the existence of networks that took shape between the wars, that source had dried up by the late 1960s. This necessitates the identification of other factors that could explain the continuity, and even the further development, of this circulation.

There was significant generational renewal in international organizations from the 1970s onward. At UNCTAD, most officials in the Division for Trade with Socialist Countries in the 1980s were between 30 and 40 years old. As a group, they had grown up and been educated in a bipolar world where the existence of "different economic and social systems" was a given. This kind of international experience is etched in the biographies of the Division's young officials of the time: Bijan Eslanloo, an Iranian hired by UNCTAD in 1978, had previously negotiated trade agreements for Iran with North Korea and Vietnam; the Finn Eila Jounela had worked at a Finnish trade agency in Eastern Europe

56 On Stein and Schönbaum's role, see Sandrine Kott, "Par-delà la guerre froide: Les Organisations Internationales et les circulations Est-Ouest (1947-1973)," Vingtième siècle. Revue d'histoire, No. 109 (2011): 143-55, doi: 10.3917/vin.109.0142.

57 File P1289, ILOA, Geneva.

58 File P3926, ILOA, Geneva.

59 Letter, Rens to Morse, July 24, 1957, file TAP 14-57, ILOA, Geneva. See also Alvin Z. Rubinstein, The Soviets in International Organizations: Changing Policy Toward Developing Countries, 19531963 (Princeton, NJ: Princeton University Press, 1964). 
before coming to UNCTAD in 1981; the Soviet Igor Artemiev spoke Spanish and English and had already been a specialist in the Americas at the Academy of Science in Moscow before his transfer to UNCTAD, for the period 1981-1986. These three examples of individuals who were under 40 in the 1970s show that the lasting context of peaceful coexistence ended up producing social conditions propitious to maintaining and renewing circulation between the two blocs. This benefit is also found in the kinds of careers these individuals had: while most of those who came from countries of the West and South had had governmental or academic experience prior to pursuing long-lasting careers in international organizations, their peers from the East were only temporarily transferred from their original institutions and were then returned to them with a higher rank. The circulation of individuals was thus favored by the career model that Eastern European states imposed on their senior civil servants. Starting in the 1960s, the community of experts from East and West would find fertile ground for cooperation in their competing but shared development policies for countries of the global South.

\section{The East as Bridge between West and South}

The notion of the "Third World" emerged in the 1950s, based on a distinction between developing and developed countries that would help to reduce the divisions created by the Cold War and bring the trajectories of the European countries in both blocs closer, sometimes to the point of merging their interests. In this context, Eastern European countries sometimes played a distinctive role. Between the world wars, they were the under-developed periphery of Europe and the locations of the first international development programs. During World War II, the Polish economist Rosenstein-Rodan, an expert in development who would soon become an official at the World Bank, described them as experimental spaces for development and as models for the countries of the global South. ${ }^{60}$ Regardless of such labels, after 1945 the countries of the East achieved economic development independently through socialist economic policies. From the 1950s onward, the appearance of the "Third World" on the international scene

60 Paul N. Rosenstein-Rodan, "Problems of Industrialisation of Eastern and South-Eastern Europe," The Economic Journal 53, No. 210/211 (June - September 1943): 202-11; Paul N. RosensteinRodan, "The International Development of Economically Backward Areas," International Affairs 20, No. 2 (April 1944): 157-65. On Rosenstein-Rodan as well as other Polish economists, see Michele Alacevich, The Political Economy of the World Bank: The Early Years (Redwood City, CA: Stanford University Press, 2009). 
not only contrasted a developing South in opposition to a developed North, but also reflected the previous relationship between East and West that was a legacy of the inter-war period and was still evident in international organizations. Actors in these organizations saw Eastern European and Balkan countries as a sort of intermediate zone between the West, seen as the center, and the underdeveloped periphery.

Experts in international organizations thus facilitated the circulation of knowledge and skills from West to East, and then to the South. Examples of this can be found in Poland, which sent grantees to the West for ILO training on the occupational integration of disabled persons, who then in turn began offering a seminar on the subject (with the ILO's help) in Warsaw for African and Asian countries. ${ }^{61}$ The organization's support for this Polish initiative indicates a common vision of Eastern European countries as central to promotion of the development policies intended for Southern countries. In this vision, Bulgaria had a privileged role. Management experts from the ILO Office organized training for personnel from the Bulgarian Institute for Social Management and then encouraged the Bulgarians to export the knowledge they gained to Cuba in the form of seminars in the early 1980s. ${ }^{62}$ More generally, the ILO experts hoped to make Bulgaria a major center of training in management techniques for recently decolonized countries. ${ }^{63}$ The same mindset reigned in other fields, such as mountain agriculture. In 1970 Jean Ozet, director of the ILO's office for the rural sector, encouraged the creation of a Center for Rural Development in Bulgaria that he claimed could be a "hub" of learning for Southern countries. ${ }^{64}$

A similar phenomenon could be found in the WCC. The WSCF had invited Hromádka to its world congress in India already in the inter-war period, when Visser 't Hooft saw him as a representative of "one of the so-called new countries of Europe," able to speak to the youth of "East and West." Hromádka was considered to possess a "double authority" based on the fact that he was from a country that was both European and developing, from a theological (but also social and political) point of view. ${ }^{65}$ The same logic held 40 years later, but with more global resonance, when the WCC in 1966 organized a world conference in Geneva on the theme "Church and Society." This conference facilitated unprecedented

\footnotetext{
61 File TAP 14-119, ILOA, Geneva.

62 File UNDP 10-2-B-2-1-1, ILOA, Geneva.

${ }^{63}$ File UNDP 10-2-C-2-2 (2), ILOA, Geneva.

${ }^{64}$ Jean Ozet to Blanchard, 11 October 1970, File MI 221, ILOA, Geneva.

65 Correspondence file, Josef Lukl Hromádka (1928), Archives of the World Alliance of the YMCAs, Geneva.
} 
participation by countries from the global South. It contributed to expanding the WCC's global reach, shifting the North-South balance within the organization, and addressing new issues such as development. ${ }^{66}$ This encounter was a shock to Westerners, who were concerned by recourse to notions of revolution and revolutionary violence "to bring about more rapid development." 67 Czech theologians offered themselves, once again, as mediators between the West and South, based on their own experience of socialist revolution. In a series of articles published in English- and German-language theological reviews in the latter 1960s, they analyzed contemporary revolutionary movements against the background of revolutionary elements of the Gospel and emphasized intersections, parallels and convergences between different geographical areas and historical periods. ${ }^{68}$ Strikingly, the Czech theologian Lochman was invited to the organizing committee of the Geneva conference. Two years later, he was also named chairman of the key Section III (for development) of the WCC General Assembly held in Uppsala in $1968 .{ }^{69}$

UNCTAD's activities in its Division for Trade with Socialist Countries also illustrate how Eastern European countries could be used as a conduit connecting West and South. This division did not much concern itself with intra-European trade, which fell more under the responsibility of the UN Economic Commission for Europe. ${ }^{70}$ It did get involved, however, when intra-European relations could have consequences for trade with Southern countries. ${ }^{71}$ This was the case with so-called "tripartite industrial cooperation," which, in the spirit of détente between the superpowers in the 1970s, was intended to associate economic actors (businesses, governmental agencies) of the East and West in assisting the growth of a third country of the global South. ${ }^{72}$ This division's mission was

\footnotetext{
${ }^{66}$ Kunter, Schilling, Globalisierung der Kirchen, 38-48.

67 Report for the Executive Committee, February 1967, File 38.0009, WCCA, Geneva.

68 See especially Communio viatorum 10, No. 4 (Winter 1967); but also Scottish Journal of Theology 21 (1968), and Evangelische Theologie 27 (1967).

${ }^{69}$ File 34.008/10-12, WCCA, Geneva. After the Soviet invasion in August 1968, Lochman decided to leave Czechoslovakia. Thanks to his extensive network of contacts in the West, he became professor of systematic theology at the University of Basel.

${ }^{70}$ UNCTAD Research Programme Division for Trade with Socialist Countries, October 11, 1974, UNCTAD, Trade and Development (TD) 802/1, UNA, Geneva.

71 Ibid.

72 On this point, see Sarah Lorenzini, "Comecon and the South in the Years of Détente: A Study on East-South Economic Relations," European Review of History/Revue européenne d'histoire 21, No. 2 (2014): 183-99, doi: 10.1080/13507486.2014.888708; Francis Arkwright and Patrick Gutman, "La coopération industrielle tripartite entre pays à systèmes économiques et sociaux différents, de l'Ouest, de l'Est et du Sud,” Politique étrangère 40, No. 6 (1975): 621-55.
} 
to conduct a survey of these cooperative ventures, analyze them and formulate recommendations to promote similar programs. In that spirit, the Division for Trade with Socialist Countries held a seminar in December $1975,{ }^{73}$ during which it submitted for discussion its initial study, published in June $1974 .{ }^{74}$ The Division's director, Mikhail Davydov, went on to participate in a conference organized by the GDR Academy of Sciences in Dresden in March $1976,{ }^{75}$ which was attended by academics from the United States, the USSR, Poland, and Great Britain. Among them were the Austrian Franz Nemschak, director of the Vienna Institute for Comparative Economic Studies, from which Davydov later ordered a study of tripartite industrial cooperation in $1978 .{ }^{76}$ An identical order was given to the West German economist Klaus Bolz of the Hamburg Institute of International Economics. ${ }^{77}$ In 1979, UNCTAD published yet another study on the same topic, probably authored by Davydov himself. ${ }^{78}$ Starting in 1981, the topic of tripartite cooperation was handed over to a new official in the division, Eila Jounela. Using her experience in Finnish trade agencies operating in Eastern Europe, she increased contacts with academics in Germany, Austria, and Hungary; with representatives of governmental ministries and banks of Eastern European countries; and with engineers and sales directors in companies in the Federal Republic of Germany (FRG) (Siemens), Switzerland (Müller Martini AG), and Austria (Voest Alpine). ${ }^{79}$ Jounela prepared a third and final UNCTAD produced study on the subject in $1984 .{ }^{80}$

The actual scale of tripartite cooperation should not be overestimated: there were only 140 projects in 1975, which made up only 6-7\% of all finalized agreements between the East and West in 1979, and represented a "marginal share" of trade with Southern countries. ${ }^{81}$ Tripartism nonetheless enjoyed special attention

\footnotetext{
${ }^{73}$ Report on the Seminar of Industrial Specialization through Various Forms of Multilateral Cooperation, held in the Palais des Nations on December 2-5, 1975, February 23, 1976, UNCTAD Trade and Development Board (TD/B) 599, UNA, Geneva.

74 Motivations, patterns, problems and prospects in industrial co-operation between enterprises of socialist and developing countries, June 21, 1974, UNCTAD TD/B 490, UNA, Geneva.

75 UNCTAD and tripartite industrial co-operation, March 25, 1976, UNCTAD TD 830, UNA Geneva.

${ }^{76}$ File UNCTAD TD 820/5(2), UNA, Geneva.

77 Ibid.

78 Tripartite industrial co-operation and co-operation in third countries, April 20, 1979, UNCTAD TD/B 243, UNA, Geneva.

79 File UNCTAD TD 820/5(2), UNA, Geneva.

${ }^{80}$ Recent developments in East-West co-operation in third countries and in tripartite co-operation, June 6, 1984, UNCTAD TD/B 1000, UNA, Geneva.

81 File UNCTAD TD/B 243, UNA, Geneva.
} 
from organizations like UNCTAD because it reinforced a pre-existing UNCTAD goal, making Eastern European countries intermediaries between West and South. The 1979 study was an example of an agreement anticipating "not only the construction of industrial facilities in Bulgaria [by a Belgian business consortium] but also a joint study for the delivery of this kind of facility, specific machines, complete production lines, and certain goods to a third country." 82

Likewise, Davydov's presentation at the 1976 Dresden conference presumed a similar division of managerial and productive tasks, affirming that "the Western partner may possess certain managerial technologies or skills that might lead to the success of the project," while "socialist countries may show themselves capable of more innovation to adapt to the host country's demands." 83 These statements still resonate, especially because tripartite cooperation was a specifically European phenomenon that only tangentially concerned the competition between the two superpowers. In 1979, nearly ninety percent of such agreements were found in Western European countries (the FRG and France, followed in time by Italy and Austria) and in Eastern European countries (Poland and Hungary, followed by Czechoslovakia, the USSR, and Romania).

Eastern Europe's position on the near periphery of Western Europe was never explicitly recognized in the work of UNCTAD experts, however. The first report on tripartite industrial cooperation indicated that "each kind of cooperation has distinctive elements, advantages, and limitations." 84 To understand this statement, a reminder of the objective that UNCTAD had set for itself is in order: to arrive at a worldwide structural adjustment, applicable to both developing and developed countries, that would be capable of creating material and institutional conditions for genuine free trade, rather than merely lowering tariffs and barriers. ${ }^{85}$ This objective explains UNCTAD's interest in the planned economies of socialist countries, which it saw both as interlocutors in a possible multilateral negotiation (among sovereign states) and as instruments of economic implementation (of the UNCTAD plan). Eastern Bloc countries, well aware of this interest, tried to respond by abandoning their Cold War rhetoric and converting their ideological goals into objective advantages: long-term intergovernmental

82 File UNCTAD TD/B 243/Supp. 5: \$23, UNA, Geneva.

${ }^{83}$ UNCTAD and tripartite industrial co-operation, March 25, 1976, UNCTAD TD 830, UNA, Geneva.

${ }^{84}$ File UNCTAD TD/B 490, UNA, Geneva.

85 Johanna Bockman, "Socialist Globalization against Capitalist Neocolonialism: The Economic Ideas behind the New International Economic Order," Humanity: An International Journal of Human Rights, Humanitarianism, and Development 6, No. 1 (2015): 109-28, doi: 10.1353/ hum.2015.0010. 
trade agreements, the acceptance of reimbursement for exports in kind or in national currency, guaranteed technology transfers, ${ }^{86}$ and certainly the prospect of reallocating the international division of labor. ${ }^{87}$ The Council for Mutual Economic Assistance (also known as Comecon, or CMEA) was also showcased by UNCTAD, partly as a regional organization likely to interest other geographical groupings ${ }^{88}$ and partly as a multilateral intergovernmental organization providing a model for trade negotiations. ${ }^{89}$

UNCTAD's interest in socialist countries led its officials to characterize them more as a model for development than as a conduit for it. They sometimes even went so far as to reproach Eastern European consultants for having a vision "devoid of any Marxist analysis and careful to never critically compare projects backed by socialist and capitalist countries." ${ }^{\prime 0}$ In that sense, East-West conflict was something to overcome, but it was best to keep the different economic and social systems, because they facilitated the accumulation of different experiences thought to be useful to advancing the international structural adjustment the organization was working to achieve. This acceptance of two equally viable models resonated well among officials of the Division for Trade with Socialist Countries, most of whom grew up after 1945. They took the existence of two stable competing models as a given, and at least those who hailed from the countries of the global South considered themselves halfway between East and West: simultaneously critical of their limitations and open to reciprocal exchange of ideas. ${ }^{91}$

\section{Conclusion}

Case studies of the ILO, WCC, and UNCTAD demonstrate, on the one hand, the remarkable diversity of the configurations that were possible inside international organizations during the Cold War. On the other hand, the studies indicate a number of important common features and tendencies that help explain the stability and persistence of circulation of experts and their expertise

\footnotetext{
${ }^{86}$ File UNCTAD TD/B 243, UNA, Geneva.

${ }^{87}$ Statement by the Secretariat to introduce item 10 - Trade among countries having different economic and social systems - at the $15^{\text {th }}$ Session of Trade and Development Board, August 1 , 1975, UNCTAD TD 804, UNA, Geneva.

88 Especially in the Middle East; see From Pankine to Senin, March 7, 1974, and TD 806/5, Davydov to Velkov, January 12, 1981, UNCTAD TD 808/1, UNA, Geneva.

${ }^{89}$ Letter, Davydov to Luft, May 5, 1980, UNCTAD TD 808/1, UNA, Geneva.

${ }^{90}$ Letter, Ganiastos, December 16, 1977, UNCTAD TD 588/1(3), UNA, Geneva.

${ }^{91}$ Bijan Eslanloo (former UNCTAD officer), interview with authors, July 13, 2015.
} 
in management, development and secularization across and beyond the great East-West divide. We specifically identified countries that had constructed a role for themselves as go-betweens since the early days of internationalism in interwar period. They produced several generations of actors in international organizations that assured the continuation of flows between two halves of the European continent despite the ideological differences represented by the Iron Curtain. Czechoslovakia and Poland stand out as reservoirs of this expertise, mainly in the case of the ILO and the WCC. That interwar legacy of personnel constituted, without any doubt, an essential part of the social and symbolic capital represented by the international experts coming from these nations even in the 1950s and 1960s.

Furthermore, we have been able to reconstruct another important dimension of the coherence and influence of these groups of experts from both East and West: their shared persuasions and culture, based on similar (Euro-Atlantic) conceptions of modernity and modernization, which formed the basis for a common (expert) language that facilitated dialogue and cooperation with colleagues from the other side of the Cold War barricade. These convergent characteristics were only reinforced by the growing role of the "Third World" in the rhetoric and deeds of international organizations. Rapidly rising interest in the notion of development in post-1945 internationalist discourse, together with more or less explicit thematization of Central and Eastern Europe's position on Europe's near-periphery further strengthened the (sometimes) advantageous intermediate position of the "second world" between West and South.

The case of UNCTAD enriches these findings in yet another way. We observed in UNCTAD the appearance in the late 1960s of a new generation of East-West-South mediators when the heirs of pre-cold War intra-European networks left the scene. This phenomenon illustrates the underlying and overarching importance of the experts who made reality intelligible and offered economic and social engineering-based solutions for modernization, irrespective of Cold War political divisions.

Can we conclude, however, that these actors constituted a genuine "epistemic community?" In fact, these groups of officials, experts, and students continued working on the production of shared knowledge and even creating a common specialist culture that could be qualified as an episteme. It was not a foregone conclusion that they would form a community as such. The identities and the strategies of these experts were not limited to establishing discursive norms and advancing the intellectual work in progress in international organizations. Their biographical trajectories were diverse. They could just as well have applied the 
skills they gained from working in an international organization to other fields of endeavor. This observation calls for a reexamination of the notion of epistemic community as a process rather than a fixed reality.

At the same time, reconstructing the history and following these groups opens a new perspective, which leads to a possible re-consideration of the Cold War as a global moment when the three "worlds" built a new kind of relationship. Beyond the bellicose rhetoric (and practice) that characterized the global conflict, it was also a time when skills circulated between competing but similar systems. International organizations proved to be particularly rich sites for observation that allows us to shed light on this hidden aspect of the Cold War and to understand the speed of the political changes that occurred in the 1990s. 